\title{
Tobacco, the Labour Bottleneck and Politics of Food Security in Sirisia, Bungoma County, 1975-2005
}

\author{
Ndalilah Joseph W \\ Lecturer \\ History \& Public Administration \\ University of Kabianga \\ Kenya \\ Professor Nicholas E. Makana \\ Department of History \\ Political Science \& Public Administration \\ Moi University \\ Kenya \\ Dr. PriscahTanui \\ Department of History \\ Political Science \& Public Administration \\ Moi University \\ Kenya
}

\begin{abstract}
The study investigated the impact of tobacco on food security in Sirisia, Bungoma County using the concepts of innovation, adaptation and commercialization. The study applied these concepts to explain how the tobacco scheme was built upon a repressive and sustained work regime among peasants at the expense of food production. The concept of innovation embraces the dynamism of African peasants and therefore, contradicts analyses that portray them purely as an amorphous mass of subsistence cultivators. Adaptation on the other hand was used to explain the copying mechanisms and the link between indigenous forms of production and the ideas, techniques and new approaches introduced by the agents of capitalism. Commercialization presupposes the changes embraced by African peasant households in response to market forces. Sirisia, accordingly, is an illustration of this state of affairs particularly in our analysis of the impact of tobacco cultivation on food security trends in the period 1975 to 2005. The paper holds that with tobacco commercialization, tobacco labour demand and food insecurity were inextricably intertwined. To survive, peasants had to take on specific strategies to overcome food deficits. The paper was based on archival research, oral interviews as well as analyzing literature on tobacco in history.
\end{abstract}

Keywords: Labour Bottleneck, Food Insecurity, Social Basis, Politics, Coping, Food Crisis

\section{Introduction}

The integration of a peasantry into the international capitalist system through commercialization of agriculture such as tobacco production has occupied the interest of a number of scholars (Chilote, 1974, Chilote, R.H. 1984, Boeke, 1961, Dos Santos, 1970 and Boesen \&Mohele, 1979). The works of Mynt (1965), Levin (1960), Forbes (1984), Mintz (1985),Bryson (1981), Babalola (1993), Muhereza (1995), Aliro (1993) and Otieno (1998), for example, represent attempts by social scientists to come to grips with the issue through an analysis of the impact of the tobacco production system on African agriculture. These scholars hold the view that, commercialization of agriculture such as through tobacco production had a negative impact on African agriculture in general and food availability. Otieno and Aliro for instance, envisage that, apart from the shift to commercial tobacco production by the peasantry, tobacco production led to a decline in African agriculture and environmental degradation. These views are shared by Stubbs (1985),Rubert (1997),Wilbert (1991),Goodman (1993),de Jesus (1985), Goodspeed (1954),Murrow (1994)and Ndalilah (2015)who albeit in different environments also discussed issues relating to the tobacco plant and its history. 
The main focus of these works has been its origin and spread from the Western Hemisphere to the rest of the world. These works often note persistent beliefs that the plant was a panacea, especially during the sixteenth and seventeenth centuries when Europeans became obsessed with it (Murrow, 1994). Some have explored the political debates that the plant engendered as others have centred on its role in indigenous practices, including detailed accounts of the pipes used to smoke it. Some other works have linked its use to the spread of psychoactive substances (Scott, 1982., Wilbert,1987).

Therefore, the tobacco plant and its history have attracted a lot of scholarly attention. Different views on its use and history have held sway in the history of the world in the past fifty years (Scot, 1982.,deJesus, 1985.,Boeke, 1942., Boesen \& Mohele, 1979).Despite the wealth of material about tobacco, scholars have not adequately explored the process by which tobacco not only became a commodity but also part of world history. Yet, tobacco and mankind have coexisted for centuries (Gately, 2001). As this crop spread, its supposed virtues secured for its great reknown, sages wrote in its favour, poets sang its praise, novelists eulogized it in tales as diviners embodied it. Spencer writing under its inspiration called it "divine tobacco" (Spencer, 1984), while Wilbert terms it "our holly herb nicotiana,... the smoke of the Gods" and that "it soothes the mind and sobers thought", (Wilbert,1987).To some scholars it is a historical icon (Van Willingen\&Eastwood,1998, 3). More elaborately, Werner, in a preface to his masterpiece, Tobacco land, echoes its social fabric calling it not only as a sort of fellowship, but as a vast domain of democracy wherein we find gathered people of every class and creed, a bond of sympathetic understanding, contact and good fellowship (Werner, 1939).

These accounts describe tobacco not only as an impetus but as a very popular crop in many parts of the world, Kenya included. The critical question is: how did this crop acquire modern negative peculiarities? While drawing upon reported evidence from the history of the crop, Geist holds that the impact of the crop is overly negative. He blames this on what he calls "Western style of agro-capitalism"' (Lohnert \& Geist, 1999).

Proponents of both the surplus approach and modernization theory stress the positive effects of cash crops such as tobacco on rural Africa (Palmer \&Parsons, 1983). Underdevelopment theorists and some Marxist scholars have come to a radically different conclusion (Nabudere, 1979). They emphasize that tobacco was an uncertain and unremunerative crop(Brass, 1990). However, proponents of the tobacco industry have argued that tobacco boosts local tobacco growing economies by helping to stem rural to urban under-employment, unemployment and the influx of people from rural to urban areas (Mamdani, 1996). It alleviates the social and economic problems associated with surplus labour by providing gainful employment to peasant growers (Muhereza, 1995).

However, the impact of tobacco on the incomes and standards of living of the tobacco-growing households has generally been underplayed (Daily Nation, January 13, 2006).Kweyu (1997), argues that there is no comparable replacement for tobacco in developing nations' agricultural programmes, since in many countries, the rural prosperity created by tobacco helps prevent the drift back to subsistence farming and the movement of the population to urban areas..., it complements and benefits food production(Aliro, 1993). Such arguments posit tobacco growing as contributing greatly towards the 'modernization' of the rural countryside and leave no room for contrary points of view (seeAliro1993).

As to how tobacco reached Kenya in particular, there have been suggestions that it reached the interior of Kenya through Arab influence via long distance trade while other sources point to Portuguese presence on the Kenyan coast. This exotic tobacco venture was quite limited until when the BAT and the Kenya government embarked on the plan to make the country self-sufficient in tobacco production. But tobacco, it must be emphasized, was native to Sirisia and grew wildly like weeds. Some other sources suggest that tobacco crop originated from Nilotic communities and from the Bugishu from Uganda. What is important is that indigenous tobacco was also grown on small scale by peasants long before the establishment of exotic tobacco. The Babukusu, for example, have had a long association with the crop.

Production and use tobacco have been issues of great controversy. The concern has been expressed not only in respect to the health hazards associated with the consumption of tobacco but also with the environmental impact of its production (Khaoya, 1992). Although tobacco production creates employment and generates foreign exchange, these benefits seem outweighed by the negative effects the crop has on the economy of the tobacco growing households (Boserup, 1965, 1981)).This dilemma has been particularly evident in Sirisia, Bungoma County. 
According to Bernstein, capitalism such as through tobacco commercialization as was the case in Sirisia, destroyed the indigenous economy which was characterized by kinship production and exchange through withdrawal of labour (Valentine, Bernstein \& Brass, 1992.).

This, constrained the indigenous economy, forcing peasants into either wage labour or commodity production. In that case, indigenous production was altered to adapt itself to the interests of BAT. This study examines the impact of tobacco on labour and food security. As a prelude, it analyses the social basis of food insecurity in Sirisia during the tobacco regime (1975-2005). It holds that labour provision for commercial tobacco production, food shortage and environmental degradation were not only rampant but inextricably intertwined. Thus, tobacco commercialization in Sirisia, like any other capitalist agriculture, produces one of the most profound examples of labour poverty. While tobacco harvests could have been plenty, peasants and their families were malnourished and hungry. Further, the paper argues that the tobacco regime in Sirisia precipitated an unprecedented region-wide subsistence crisis punctuated by periodic famines. To cope with food crises, peasants in Sirisia attempted to anticipate and counteract food crises using a repertoire of strategies. Thus, food insecurity and hunger were integral features of the tobacco regime in Sirisia in the period 1975-2005. The land use pattern was also changed from one of mixed farming to dominance of a single cash crop-tobacco (tobacco monoculture).

Need to Understand the Impact of Cash Crops on Food Security

A lot of literature has emerged and the issue of the impact of cash crops on peasant sector is presently a central theme in Kenyan history. However, the impact of tobacco commercialization on labour and food security specifically in Sirisia has been one of the most neglected yet interesting stories which remain to be told in full. Earlier works dealt with labour on European farms and towns, ignoring the peasant sector in rural areas such as Sirisia. Some of the early studies are also generalized works hence scholars need to study at micro level and present a systematic analysis. Not only is it important to focus attention on the impact of Multinationals through tobacco cultivation on both labour provision on tobacco farms and food insecurity but the period upon which the research centres represents an important epoch in Kenya's Bukusu Society and economy who formed majority of peasant tobacco farmers in Sirisia.

This study examines the impact of commercial tobacco cultivation on labour organization and food security in Sirisia, Bungoma County in the period 1975-2005 particularly on a community that previously had a predominantly mixed economy. The paper attempts to answer a number of questions such as: What was the impact of tobacco commercialization on labour in Sirisia? What were the social basis of food insecurity?, What other prevalence occurred as a result of tobacco commercialization? How did the peasants react to food unavailability? How did tobacco commercialization in particular contribute to malnutrition and disease?

\section{Materials and Methods}

Sirisia is part of the Bungoma-Busia tobacco growing region and is located between longitudes $340 \mathrm{E}$ and $350 \mathrm{E}$ and the latitudes 00 and 10N 9 (Republic of Kenya, 1997-2001). Sirisia is located in Bungoma County, one of the administrative regions in Kenya. Specifically, the area is part of the wider Amagoro, Amukura, Kanduyi, Nambale and Sirisia (with the main tobacco hub at Malakisi) tobacco growing areas. The area has a high human population. This is attributed to conventionally rain fed agriculture practiced in this region. The soils are rich and suitable for mixed farming except in some parts like Chebukutumi, Bisunu, Butonge, Namutokholo, Yabeko, Kabuchai and Chongoi whose soils are underlain by hardpans (Republic of Kenya, 1999).

This paper was based on primary sources which were sought through oral interviews in form of field interviews and eye witness accounts. By use of question guidelines the informants were allowed to talk freely on the topic of study. Archival sources were then used to supplement oral interviews. More data was obtained from BAT Annual Reports, Bungoma District Development Plans, Reports from the Ministry of agriculture, ministry of Environment and Statistical Abstracts. Other sources included books, Journals, Newspapers, Magazines, Articles and Theses.

\section{Results and Discussion}

The Social Basis of Food Insecurity in Sirisia, 1975-2005

The issue of food security in Sirisia was a matter of debate between 1975ands 2005. It is important to note that though food shortage and environmental degradation were rampant after the introduction of tobacco in Sirisia, it nevertheless became much more pronounced in the period 1975 to 2005 . 
Both food insecurity and environmental change were key impacts of tobacco commercialization in Sirisia. At the same time, environmental change had an even greater impact on food production. For example continued overuse of the same farms altered the soil PH and made germination of food crops poor. In cases where crops germinated, they did not do well because the nutrient level was low. Poor crop yields led to regular famines which oral accounts and BAT records attributed to poor planning on the use of food available (sic) (KNA/ BV/6/573). These sources gave different perceptions on the causes of both food security and environmental change in Sirisia in the period 1975 to 2005 . According to some sources, it was not obvious that tobacco commercialization in Sirisia led to these changes. For example, Michael Mwangi, a Tobacco Inspector noted that; At harvest time, the peasants miscalculate their food requirements; they sell too much of their produce and consequently suffer from hunger. They don't think of tomorrow. Much of what they harvest end up on the market, sometimes far in the event that they need the same in future (Michael Mwangi, a Tobacco OI, Inspector, September 27, 2009).

The same was echoed by Martin Wafula, another tobacco Board Inspector to the BAT; Hunger periodically rages throughout much of Sirisia. It is caused primarily by the decline in the cultivation of food crops which results from siphoning off enormous amounts of labour to cultivate tobacco. That has been the trend in Sirisia since the introduction of tobacco on commercial basis (Martin Wafula, tobacco Board Inspector, OI, September 27, 2009).

On environmental change Andrea Ndalila observed that; It is sad these days, tobacco can no longer do well. The land is bare, it is hot. We have no food. Trees have been cleared over the years to meet the high demand for wood fuel required in tobacco curing. The best world in which we lived has been taken from us, rivers are drying up, forests are gone. We are now poor; we cannot educate our children...Sirisia was never like this!(OI, Andrea Ndalila, September 28, 2009).

Why this scenario? Wafula was right. Contrary to the assertion of his colleague, food shortages in rural Sirisia were not self-induced. Indeed the tobacco regime precipitated an unprecedented region-wide food (subsistence) crisis punctuated by periodic famines, enjala. In this case, peasants in Sirisia underwrote the tobacco industry with their labour and sacrificed their food security for tobacco in the years 1975 to 2005 . The burden on women's time was also particularly acute. If the intensity, duration and scale of the food crisis during the tobacco regime in the period under study were unprecedented, malnutrition was also not unique (see section on tobacco, malnutrition and disease). Seasonal food shortages and long-term famines antedated the tobacco scheme. According to oral accounts, although there was prevalence of food shortages since the introduction of commercial tobacco cultivation in Sirisia, certainly they recurred with disturbing frequency in the period 1975 to 2005. On this point, one respondent from Mwalie Location was in agreement: Famines have been a recurrent problem in Sirisia since the entry of BAT. In the past when it rained, our granaries were full. This changed after the establishment of tobacco farming. Land available can no longer support food crops because of soil exhaustion and most people are addicted to growing tobacco (OI, Margaret Namachanja, July 30, 2010).

During the initial period, peasant tobacco farmers in Sirisia vividly recounted the devastating effects of rural subsistence crises (OI, Christina Machuma, October 29, 2009). Famines in Sirisia, often described differently, are documented for 1978, 1980, 1984, 1990, 1992 and 1997. The famine of 1984 "Enjala ye Gorogoro" (the famine of the two kg tin) for example, recalls the hunger and destitution brought by devastating drought in 1984 which destroyed maize fields particularly and food supplies in general. Oral accounts also point to the fact that there was frequency in famine between 1975 and 2005 in the tobacco growing hub of Bungoma-Busia region. According to Margaret Namachanja, there were subsistence crises (OI, Margaret Namachanja, July 30, 2010). These crises were attributed to natural disasters, particularly drought and pestilence, as well as devastation of the countryside (Sirisia) due to the introduction of commercial tobacco farming (OI, Andrea Ndalila, September 28, 2009). In particular commercialization of tobacco in Sirisia heavily disrupted local food economies (OI, Margaret Namachanja, July 30, 2010).

Just as famines were not simply "natural" events in pre-tobacco Sirisia, they cannot be understood in isolation from the transforming influences of capitalism (in this case manifested through tobacco commercialization). For example, the introduction of wage labour, the shift to cash crop production, the spread of Multinationals (in this case BAT) and post-colonial marketing policies, affected rural food security in Kenya generally and in Sirisia in particular (1975-2005). Thus, the historical analysis of the food situation in Sirisia, therefore, cannot ignore the process of rural differentiation and increasing unequal access to the scarce resources that characterized the peasantry during the period 1975 to 2005 . 
To stress the social basis of famine in Sirisia is not in essence to diminish the role of environmental factors in determining food security. At times, there were uncertain and relatively short rainy seasons which were a critical variable in food production in Sirisia. This, as observed elsewhere in this study, was due to wanton destruction of vegetation cover in the process altering the hydrological cycle. The southern part of Sirisia in particular suffered regularly from droughts and the fact that it had fragile infertile soils fully accounts for low food production. These seasonal hot spells imposed constraints on agricultural production in the period 1975 to 2005. Pests, diseases and soil erosion also destroyed the food economy in Sirisia.

The tobacco scheme in Sirisia as observed, was predicated on the ability of the BAT Company to divert household resources, particularly labour, from the food economy and into commodity production. It was a decision based on the politics of production and the more the BAT appropriated peasant labour (jeopardizing peasants' strategies to avoid famine), the more peasant tobacco growers became vulnerable to hunger (OI, Phylis Ndalila, July 24, 2009). Millet, sorghum and coffee production generally declined despite the initial expectations that the growth of tobacco would spur prosperity in Sirisia. Tobacco agriculture therefore soared in particular, out of the need to get money to meet subsistence needs. Peasant tobacco farmers in Sirisia had earlier taken a huge gamble on tobacco as opposed to other crops and in particular food crops. One informant held that:

In tobacco, the big gambler is the grower himself. He has no guarantee of anything. He takes a chance on raising his crop and does not know what it will fetch. If the crop fails, then, that is it. It is a ninety day crop growing but, with curing it takes five months. On the whole, they are five risky months (OI, Martin Wekesa, February 12, 2009).

Maize, sorghum and millet were the staple food crops in Sirisia before the introduction of tobacco. However, the growth of tobacco in Sirisia affected production of these crops between 1975 and 2005 in two ways. First, peasants paid less attention to the cultivation of these staple crops since they could (as they said) make more money from tobacco. Secondly, tobacco cultivation, exhausted soils because of constant and heavy application of fertilizers and chemicals (Khaoya, 1992). Farms previously planted with tobacco therefore, discouraged the cultivation of maize and other food crops like sorghum and millet. Particularly, the decrease in maize production had a negative impact on food security in Sirisia in the period 1975 to 2005. In addition, since BAT interests controlled the terms of exchange, peasant farmers had little disposable income with which they could purchase the food they no longer grew. The results were predictable; food shortages and local famines occurred with regularity in Sirisia with the peak being the period between 1975 and 2005.

Apart from that, there is also need to stress the seasonal dimensions of rural impoverishment in Sirisia in the period 1975 to 2005 . The wet season preceding the harvest particularly made peasant tobacco growers very vulnerable. Food was often in short supply causing food prices to sky rocket (Khisa, 2008). Farm work was at its most intense. Scholars working in Nigeria and the Indian subcontinent found that: Such time of year is marked by loss of body weight, low birth weights, high neo-natal mortality, malnutrition, indebtedness and abject poverty. It is the hungry season and the sick season. It is the time of the year when poor people are at their poorest and vulnerable (Chambers, Longhurst \& Pacey, 1981).

The tobacco regime simply exacerbated this tendency in Sirisia in the period 1975 to 2005. Although tobacco farming left many hungry, some peasant tobacco growers and their families were much more vulnerable than others. David Arnold's broad formulation of the politics of food security could be used to accurately describe the reality in Sirisia during the tobacco regime between 1975 and 2005 when he notes that: Historically food was one of the sinews of power. Its importance was felt at all levels of society, both by those who suffered directly for want of basic sustenance and those whose authority and security and profit were threatened as the indirect consequences of death and much starvation. Food was and continues to be power in a most basic, tangible and inseparable form (Arnold, 1988, 15-20).

Oral accounts also point to the fact that the nutritional component was mostly ignored, and many peasants in Sirisia were pushed against the margins of subsistence in terms of food availability. They ate little targeting only survival (OI, Christopher Musabi, June 26, 2010., KNA/BV/2/4).

The Labour Bottleneck and the Politics of Food Security in Sirisia, 1975-2005.

Capitalist plantation agriculture produces some of the most profound examples of labour poverty. While harvests could have been in plenty, agricultural labourers particularly in the tobacco industry and their families in Sirisia remained malnourished and hungry in the period 1975 and 2005. 
One of the most distinctive features of this period was that the peasant tobacco farming families at this time were mostly clothed in tattered garments (Arnold, 15-20). The picture drawn from the peasant tobacco farmers' conditions gives a consistent account of physical, mental and social impoverishment (Ibid). With the introduction of tobacco cultivation on commercial basis, low prices of tobacco, poor living conditions and the lack of social benefits dramatically raised the incidence of malnutrition and diseases In addition, the introduction of cash crops led to food insecurity which Armatya Sen, calls unavailability decline (Sen, 1981.51.). According to the World Bank Report "Food security" is defined as access by all people at all times to enough food for an active health life (World Bank 1986, cited in Isaacman, A, 79). It should be noted that national self-sufficiency in food production does not automatically guarantee all citizens the right to food. Oral information points to the fact that "at many times, peasant tobacco farmers in Sirisia had insufficient energy to do a full day's work, owing to low diet" (OI, Christopher Musabi, June 26, 2010).

The demands from tobacco created a serious labour problem in most peasant households in Sirisia (Otele, 2010). According to literature on agricultural production, any month in which labour requirements are greater than 15 per cent of the total annual output is considered a "bottleneck." (Richards, 1983. 1-72). It is a period when excessive labour demands are collapsed into a relatively short period. By this criterion, there were three periods of acute labour pressure in the tobacco zones in Sirisia in the period 1975 to 2005. The first was between late November and late January when peasants planted tobacco in addition to sowing their major food crops (Millet, sorghum, maize, peanuts and beans) (OI, Andrea Ndalila, July 28, 2010., KNA/MW/3/4). The second and more acute labour crisis occurred in February and March, when peasants had to transplant, thin and weed tobacco while also clearing their food gardens (KNA/15002/630). Weeds strangled food crops and lowered food production. The third was in the months of May, June and July, a period in which tobacco harvesting, curing and marketing took centre stage (Ndalilah, 2015, 31).

After working for longer hours and drawing on extra familial labour, most peasant households in Sirisia found it physically hard to sustain the food production system during the tobacco regime particularly between 1975 and 2005. Faced with this situation, peasants diverted the badly needed labour from food crops to tobacco unlike it had been since 1975 (OI, Solomon Khisa, October 28, 2010). Not only was there less time for other major crops but women had limited time to tend food crops (KNA/15002/630). Men equally failed to engage in other economic pursuits.

It is important to note that labour bottlenecks in Sirisia during this time also carried emotional and mental costs. For instance, the most acute labour crunch in January and February coincided with seasonal food shortages. According to Manuel Situma, "It was also a time of anguish for many parents who watched helplessly while young babies suffered and even died from malnutrition and hunger-related diseases" (OI, Manuel Situma, July 26, 2010). Maximila Malemo of Nabulooli was visibly moved as she told her own personal tragedy: It was terrible. We had to work tobacco and as a result could not keep up our gardens. There was no room to grow food crops and if one did then attention to the farms was not sufficient. This caused hunger. Many babies died between January and March. They died during the hunger period. It was also a time when diseases were rampant (OI, Maximila Malemo, September 23, 2010).

Generally, tobacco policies exacerbated food crises in Sirisia in the period 1975-2005. BAT's decision that tobacco had to be grown on separate fields for instance made it more difficult for peasant households to meet their food requirements. There was no compelling reason, scientific or social, why tobacco could not be intercropped with foodstuffs. To the contrary, cultivating missed fields helped to maintain soil humidity, initially increased soil nutrients and reduced erosion. BAT, however, considered it an impediment to tobacco cultivation in Sirisia. If intercropping was legalized, it would have been more difficult to oversee the daily work practices of peasant tobacco growers because they could have diverted their labour to the food economy.

The interrelationship between food and land figured profoundly at a cultural level before the introduction of tobacco. It was also a major feature of the tobacco regime in the period 1975-2005. In the pre-tobacco period, farmers conducted religious ceremonies to propitiate the ancestors before they planted and even after harvest. The most elaborate of these ceremonies took place during harvest since failing to propitiate the ancestors would have been devastating to the community (OI, Solomon Khisa, October 28, 2010). According to Khisa, a member of Dini Ya Musambwa which held sway then, "If we did not give thanks, the ancestors would get angry and worsen our situation"(Ibid). But in detesting tobacco, Albert Mumelo of Namubila held that: "If we had choice we preferred to plant food crops such as cassava, or maize, beans millet and sorghum. 
We received more from these crops than tobacco" (OI, Albert Mumelo, June, 23, 2010). So was Adelina Mukholi of Tulienge who observed that: "Food crops were important. We could not give up on them" (OI, Adelina Mukholi, July 29, 2009). For all these reasons, BAT Company officials had to induce peasant tobacco growers to prevent them from diverting their labour to other crops.

It is clear that the diversion of labour to tobacco had far-reaching impact on food security. Evidence so far adduced from the tobacco zones stressed the inverse relation between tobacco and food production (Khisa, 2008., Ndalilah,2015). By early 1984, The Daily Nation, a leading Kenyan Newspaper, had warned: The expansions of tobacco production... and of other forced cultures have had a prejudicial effect on maize, millet, sorghum, cassava, and peanuts which are indispensable to the peoples' diet and no less profitable to the producers than tobacco. It is excellent, even magnificent that tobacco production has increased... but it does not make sense for the economy that this expansion should come at the expense of food crops (Daily Nation, May 30, 1984).

Further, in a confidential report to the Ministry of Agriculture six years later, an agronomist- Martin Wafula concluded that "it is becoming increasingly more appropriate to attribute food shortages to tobacco" (OI, Martin Wafula, July 29, 2009). The situation had not improved in the late 1990s and early 1975, when the Anglican Church of Kenya (ACK) Bishop of Bungoma expressed outrage that in one of his parishes "which had been a granary of abundant food production, the commercialization of tobacco left people in the region suffering from hunger" (OI, Bishop Eliud Wabukala, July 30, 1998). Former tobacco producers in Machakha, in Namubila location remember how the tyranny of the tobacco regime in 1975 to 2005 , combined with a particularly bad weather spell in Sirisia often left them without food (OI, Masasabi Nasiuma, November 30, 2010).

Therefore, as already observed, perhaps the best documented and most tragic testimony to the devastating effects of tobacco on rural food security comes from Sirisia in Bungoma County, between 1975 and 2005. Earlier, BAT and tobacco interests unleashed a vigorous campaign against the peasant food economy, destroying it, forcing peasants to grow their food crops on tobacco-eroded soils. In the words of one Maurice Wamukota, "the richest lands were dedicated to tobacco and the poorest to cereals and other food crops" (OI, Maurice Wamukota, July 29, 2010). BAT's attack on food crops had a second important consequence on rural food security in Sirisia between 1975 and 2005. Since peasants had to privilege tobacco production, they also had less capacity to grow other cash crops such as coffee, cotton, simsim or sunflower. As a result, they lost disposable income that could have been used to purchase the foodstuffs they were unable to produce themselves. The end result was food unavailability (Sen, 77).

In summary, because peasants in Sirisia sold their tobacco under conditions which they had little control over, they assumed all the risks of production. Thus, food crises in Sirisia, then had to be situated in a larger struggle over who set the terms of commercial exchange and questions of entitlement-the totality of moral, political and economic rights that individuals and households commanded to gain access to food resources (Arnold, 67., KNA/MW/3/4).

Tobacco, Malnutrition and Disease, 1975-2005

The introduction of commercial tobacco cultivation in Sirisia, set in motion debate on the issues of malnutrition and disease eventually which became an integral aspect of its historiography. As noted earlier, food insecurity and hunger were integral features of the tobacco regime in Sirisia from its inception but became much more pronounced in the period 1975 to 2005. Tobacco practices and policies had abrogated much of the control that peasants had historically exercised over their food economy (OI, Phelisters Ndalila, July 28, 2010). Hardly a year passed during the tobacco era in which food problems were not reported in the tobacco zone of Sirisia (like the rest of the tobacco growing regions in Kenya). Government documents tended to make only brief references to rural subsistence crises, often alluding to them in vague terms such as "low food supply," which meant either hunger or famine, or used even the more obscure notion of "deficiencies." Both terms hide more than they reveal. Moreover, famine and malnutrition are not necessarily the same.

Whereas famines attracted the attention of agronomists and local administrators, they generally ignored the causes of nutritional imbalances in rural diets. As a result it is often difficult to tell from these documents the magnitude or rhythm of rural food crises during the tobacco regime especially in the period under study (1975-2005) in Sirisia. The tendency of BAT Management to presume that "seasonal famines" were natural events in Sirisia and that local diets were inherently deficient coloured most accounts of food and diseases. Palmer \& Parsons in their book The Roots of Rural Poverty in Central and Southern Africa, explored the causes of rural poverty and proclaimed that; 
"Rural folks, eat poorly and waste enormous amounts of grains making beer, which has a prejudicial effect on their health and morality" (Palmer \& Parsons, 1983) Palmer \& Parsons' observation tells us more about the assumptions of nutritional scientists than about the reality on the ground in Sirisia in the period 1975-2005.

The tobacco regime eroded a number of agronomic strategies that peasants in Sirisia had historically employed to guarantee food security. Intercropping and mixed cropping were prohibited. Most peasant tobacco farmers were, therefore, forced to reduce the range of food crops they grew. Previously, peasants were very conscious of hedging their risks by planting an array of food crops in case environmental conditions caused a shortage of the main staple; maize. Their shift to less drought-resistant labour-saving crops during the tobacco era, notably beans and horticultural crops, increased the risks of famine further. Tobacco practices not only undermined existing famine avoidance strategies, but restricted the freedom of peasants to make new adaptations. It was thus, hardly surprising that, famines occurred with disturbing regularity, particularly in central Sirisia locations, the principal tobacco zone between 1975 and 2005. The evidence that tobacco exacerbated food shortages, especially during the pre-harvest period, is even more compelling. BAT and local administrators in Sirisia openly acknowledged this fact (cited in Khisa, 2008., (Daily Nation, May 7, 2002)).

Food shortages were most acute during the pre-harvest period, which occurred during the rainy season. The connections between malnutrition and rural work were especially clear in female-headed households, where women had to cultivate their gardens, care for children, gather firewood, fetch water, assist the sick and the elderly and perform all other chores in addition to producing tobacco (KNA/15002/630). The multiple demands on women's time made it difficult for them to provide adequate food (OI, Phelisters Ndalila, July 28, 2010). Their dilemma was compounded during the peak labour periods, which came at a time when food supplies were nearly exhausted and the new year's food had not yet ripened. Oral accounts point to the fact that in Sirisia, it was during this period that women and children suffered most (OI, Justine Sikwata, July 29, 2010). Margaret Namubuya's grief in the aftermath of her babies' starvation highlights the fact that famines were as much, about feelings, vulnerability and despair as they were about caloric intake (OI, Margaret Namubuya, July 29, 2009, See also Khisa, 2008).

It is difficult to establish precisely the nutritional status of most peasants in rural Sirisia under the tobacco regime, since few dietary surveys were undertaken during the period under study. The studies that exist confirm that food intake in rural areas was neither adequate nor well balanced. Khisa came to the conclusion that: "Unfortunately, as far as can be determined, these basic requirements are not met in most rural diets" (Khisa, 2008). Oral information points to the fact that peasants in the tobacco regime in Sirisia in the period 1975 and 2005 remembered with great clarity sleeping hungry on a number of days and barely surviving on limited food (OI, Simon Masafu, October 19, 2010). The health consequences of inadequate rural diets have not been sufficiently explored to warrant definitive conclusions about the epidemiology of malnutrition, but oral accounts from women who cultivated tobacco in Sirisia and comparative evidence from other parts of Africa suggested the potentially devastating consequences of low nutritional levels combined with harsh climatic conditions (OI, Phelisters Ndalila, July 28, 2010). Women with whom the researcher interacted stressed that in Sirisia babies and young children were most vulnerable particularly between the years 1975 and 2005. Rosa Maria Nekesa of Namubila recalled that during the rainy season, "many children died from hunger and anaemia as others were left so frail that they succumbed to measles" (OI, Rosa Maria Nekesa, July 29, 2009).

There is also available evidence that gender hierarchies shaped access to food within many rural households in Sirisia between 1975 and 2005. Armatya Sen concluded that "diet often depends on age; children, especially those being breast-fed, are the most vulnerable" (Sen, 83). The opportunity for men to find wage employment also gave them a greater chance to escape hunger (OI, Emily Watila, September 28, 2010). In the final analysis, access to food at the household level in Sirisia in the period 1975 and 2005 was inextricably linked to growing disparities in power and wealth that were part of the larger process of rural differentiation sometimes leading to food shortage, malnutrition and hunger (KNA/15002/630., Khisa, 2008).

Coping with the Food Crises, 1975-2005

Faced with hunger and starvation, peasants in Sirisia attempted to anticipate and to counteract food crises. The repertoire of strategies they had at their disposal to cope with food insecurity, however, was quite restricted. In other contexts, such tactics included limiting the number of child births per family, eating less at each meal, expanding food sources, or figuring out ways of supplementing family food supplies. There is no evidence that peasant tobacco producers in Sirisia in the period 1975-2005 chose the first option. 
Oral and archival accounts also record that food consumption decreased during the pre-harvest months (KNA/MW/3/4., OI, Rosa Maria Nekesa, July 29, 2009). However, it is unclear whether peasant tobacco growers consciously adjusted their consumption patterns to guard against expected food shortages or whether they were forced to reduce their food intake because of a decline in its provision.

It was quite common for peasants in Sirisia in the period 1975 to 2005 to seek new sources of food by planting higher-yielding or lower-risk crops, such as sweet potatoes, sorghum, millet, pigeon peas and maize (OI, Solomon Naliakho, November 30, 2010). Cassava had been a staple in Sirisia upto the 1990s, but both fungal and viral diseases destroyed it (OI, Raphael Wanjala, June 27, 2010). A number of researches opine that the decline in cassava production since the 1990s in Sirisia was attributable to toxism through chemical application and tobacco induced diseases (Khisa, 2008., Ndalilah,2015). Drought-resistant cassava offered a number of advantages. Peasants grew "sweet" and "bitter" varieties of cassava (both easily intercropped with maize, sorghum, beans and peanuts), since they could be harvested last and stored easily. At the same time, it did not compete for labour with any other staples (Ibid). "Cassava was our most important food crop, it took no work; maize had to be cared for," was a common refrain (OI, Phelisters Ndalila, July 28, 2010). Most importantly, cassava could be eaten green or ripe, was high in caloric value and very filling (Ibid).

For peasants trapped in the tobacco regime in Sirisia, frequent famine reminded them of how cassava had been a critical food source during the periods of food crisis. Benjamin Mavunja from Nabulooli recalls that he and his family had little time to grow food (OI, Benjamin Mavunja, July 29, 2009). Later however, Newspaper accounts noted that "the peasants in Sirisia had already demonstrated increasing interest in turning to cassava growth, a crop less vulnerable to climate inconsistencies" (Daily Nation, May 6, 2002). This was true in the central region of Bukokholo as oral accounts from the north described a similar phenomenon: "Before tobacco, sorghum was most common. With decline of cassava we grew maize, a little millet, and a bit of sorghum" (OI, Raphael Wanjala, June 27, 2010).

On a smaller scale, peasants in Sirisia attempted to improve food security by growing more sweet potatoes. Sweet potatoes offered the same advantages as cassava. They were fast-maturing and fairly low-risk tubers that suited the short growing season of Sirisia. While sweet potatoes required more field labour than cassava, since they had to be planted in mounds and the labour ratio, calorie for calorie, was quite similar when cassava's processing time is taken into account (Isaacman, 1996). Sweet potatoes required a humid climate. However, they also grew best in riverine areas or in zones with high rainfall. For Sirisia peasant farmers, particularly in the moist lowlands surrounding Malakisi, Ndakaru and Toloso Rivers, sweet potatoes became an important dietary supplement, as they did in the wetter regions of northern and central Sirisia (Republic of Kenya, 1997-2001). In times of crises, this crop was critical in Sirisia between the years 1975 and 2005. "No one died from hunger; we always had sweet potatoes and pumpkins," recalled Kabocho Wamocho from Ndakaru (OI, Kabocho Wamocho, July20, 2009).

The other major adaptation in food cropping was the shift from sorghum to maize, particularly in the central and northern regions of Sirisia. Sorghum required more labour compared to maize, matured more slowly and was less compatible with tobacco. Peasants shifted to maize because they lacked sufficient labour simultaneously to weed tobacco and protect the young sorghum from birds (OI, Andrea Ndalila, July 28, 2010). At harvest time, labourdeficient households often had to choose between tobacco and sorghum, since both crops matured at the same time. "Because we had to give priority to tobacco, sorghum yields declined," said Joseph Kutete from Butonge (OI, Joseph Kutete, July 29, 2009). Most households had little alternative but to reduce the size of sorghum fields to avoid this labour bottleneck. Due to these reasons, sorghum gave way to maize which peasants took to in earnest, leading to decline in food production due to tobacco commercialization that begun by the year 1975 (OI, Benjamin Sulungai, July 29, 2009). That was the trend in Sirisia in the period 1975-2005.

\section{Conclusions}

The paper has discussed the impact of commercialization of tobacco on labour and food security in Sirisia in the period 1975 to 2005. It observed that the peasants in Sirisia were a dynamic society with a highly diversified economy. Division of labour was done along gender lines and societal needs. This stable ordering was disturbed by the intrusion of international capital, symbolized by BAT entry into Sirisia and commercialization of tobacco. This paper has further examined the links between commercial tobacco production and food security in Sirisia in the period 1975 to 2005.It holds that labour provision for commercial tobacco production, food shortage and environmental degradation were not only rampant but inextricably intertwined. 
The paper also stressed that labour bottlenecks in Sirisia carried emotional and mental costs, as was the case during the most acute labour crunch. From then on, food insecurity, hunger, malnutrition and disease became integral features of Sirisia historiography. As an agribusiness, tobacco cultivation in Sirisia far from being the solution, exacerbated the social inequalities that were the real causes of hunger and dependency (Burbach \& Flynn, 1980., Daily Nation, January 13, 2006). Hence, tobacco commercialization in Sirisia reflects the forces that shaped capitalism in the twentieth century. Finally, the paper noted that the imposition of exotic tobacco had thorough going implications on labour and food security in Sirisia in the period1975 to 2005.

\section{References}

Aliro, K.O. (1993).Environmental and Socio-Economic Impact of Tobacco Production in Arua District. Kampala: Panos Institute.

-(1993).“Uganda: Paying the Price of Growing Tobacco.” London \$ Kampala: Kampala Monitor Publications for Panos Institute.

Armatya, Sen. (1981). Poverty and Famines: An Essay on Entitlement. Oxford: Heinemann.

Arnold, D. (1988).Famines: Social Crisis and Historical Change. Oxford: OUP.

Babalola, A. (1992).BAT and the Penetration of Capital in Oyo State. In Review of African Political Economy.

(1993).Capitalist Development in Agriculture: The Case of Commercial Tobacco Farming in the Oyo-North Division, Oyo State, Nigeria. Lagos: Longman.

Boeke, J. H. (1942). The Structure of the Netherlands Indian Economy. New York: Institute of Pacific Relations.

Boesen, J\&Mohele, A.T. (1979). The Success Story of Peasant Production, The Political Economy of A Commodity Producing Peasantry. Upsalla: OUP.

Boserup, E. (1981).Population and Technological Change: A Study of Long Term Trends. Chicago: Oxford University press.

-----------(1965).The Conditions for Agricultural Growth: The Economics of Agrarian Change in Population Pressure. Chicago: Aldine Publishing Co.

Brass, T. (1990).Peasant Essentialism and the Agrarian Question in the Columbian Andes. Journal of Peasant Studies, 17(3).

Bryson, J.C.(1981)."Women and Agriculture in Sub-Saharan Africa: Implications for Development-An Exploratory Study.’’ In Journal of Development Studies, Vol. 17, No. 3.

Burbach, R. \& Flynn, P. (1980).Agribusiness in the Americas. London: MRP.

Chambers, R. Longhurst, R. \& Pacey, A. (eds.) (1981).Seasonal Dimensions to Rural Poverty. London: OUP.

Chilote, R. H.(1974)."A Critical Synthesis of the Dependency Literature," in Latin American Perspectives, Vol. 1. (1984).Theories of Development and Underdevelopment. London: Boulder.

Daily Nation, January 13, 2006.

Daily Nation, May 30, 1984.

Daily Nation, May 6, 2002.

Daily Nation, May 7, 2002.

De Jesus, E. C. (1985).The Tobacco Monopoly in the Philippines: Bureaucratic Enterprise and Social Change, 1756-1880.Manila:Ateneo de Manila University Pr.

Dos Santos, T.(1970). "The Structure of Dependence," in American Economic Review, Vol. 60.

Forbes, D.K. (1984)The Geography of Development. London: Biddles Ltd.

Goodman, J. (1993). Tobacco in History; Cultures of Dependency. London and New York: Route ledge.

Goodspeed, T.(1954).The Genus Nicotiana.New York: Waltham Mass, Journal of Pharmaceutical Sciences.

Gately, I. (2001).Tobacco: The Story of How Tobacco Seduced the World. New York: Grove Press.

Isaacman, P. (1996). Cotton is the Mother of Poverty; Peasants, Work and Rural Struggle in Colonial Mozambique 1938-1961.London: OUP.

Khaoya, S. (1992).A Socio-Economic Assessment of Constraints in Renewable Energy Options for Tobacco Curing in Bungoma-Busia Region, Kenya. M.phil Thesis, Moi University, Eldoret.

Khisa,G.V. (2008). The Effects of Tobacco Production on Household Food Security in Malakisi Division, Bungoma District. M.Phil Thesis, Moi University, Eldoret.

KNA/BV/6/573.

KNA/15002/630; Growing tobacco and Curing Tobacco, Fire and Air Cured Western Tobacco

$\mathrm{KNA} / \mathrm{BV} / 2 / 4$. 


\section{$\mathrm{KNA} / \mathrm{MW} / 3 / 4$.}

Kweyuh, P. (1997).Tobacco Farming in Kenya: The Profits Deception. Paris: VIATLD.

Levin, J. V. (1960).The Export Economy. Cambridge, Harvard University Press.

Lohnert, B. \& Geist, H. (1999).Coping with Changing Environments: Social Dimensions of Endangered Ecosystems in the Developing World. Singapore: Alder shot Brookfield.

Mamdani, M. (1996).Uganda Labour Studies. Dakar: CODESRIA.

Martin Wafula, Tobacco Board Inspector, OI, September 27, 2009.

Michael Mwangi, a Tobacco Inspector, OI, September 27, 2009.

Mintz, S. (1985).Sweetness and Power: The place of Sugar in Modern History. New York: Viking.

Muhereza, F. E. (1995). Agricultural Commercialization, Contract Farming and Tobacco: A Study of SocioEconomic Effects of Tobacco Growing in Masindi District, Uganda. Kampala: Heinemann.

Murrow, R.A.H. (1994).Prize Essays on Tobacco. Dayton: United Publishing House.

Mynt, H.(1971).The Economic Growth of Brazil. Los Angeles and London: University of California Press. -(1965).The Economics of Developing Countries. New York: Praeger Publishers.

Nabudere, W. (1979).Essays on the Theory and Practice of Imperialism.(Dar-es-Salaam: Tanzania Publishing House.

Ndalilah, J.W. (2015). “Agricultural Commercialization, Contract Farming and Tobacco: A Study of the Impact of Tobacco Cultivation on Employment Trends in Rural Sirisia, Bungoma West District,1975-2005.' in International Journal of Agricultural Extension and Rural Development Studies, Vol. 1,No.2.

OI, Adelina Mukholi, July 29, 2009.

OI, Albert Mumelo, June, 23, 2010.

OI, Andrea Ndalila, September 28, 2009

OI, Benjamin Mavunja, July 29, 2009.

OI, Benjamin Sulungai, July 29, 2009.

OI, Bishop Eliud Wabukala, July 30, 1998.

OI, Christina Machuma, October 29, 2009.

OI, Christopher Musabi, June 26, 2010.

OI, Emily Watila, September 28, 2010.

OI, Joseph Kutete, July 29, 2009.

OI, Justine Sikwata, July 29, 2010.

OI, Kabocho Wamocho, July20, 2009.

OI, Manuel Situma, July 26, 2010.

OI, Margaret Namachanja, July 30, 2010.

OI, Margaret Namubuya, July 29, 2009.

OI, Martin Wafula, July 29, 2009.

OI, Martin Wekesa, February 12, 2009.

OI, Masasabi Nasiuma, November 30, 2010.

OI, Maurice Wamukota, July 29, 2010.

OI, Maximila Malemo, September 23, 2010.

OI, Phelisters Ndalila, July 28, 2010.

OI, Phylis Ndalila, July 24, 2009.

OI, Raphael Wanjala, June 27, 2010.

OI, Rosa Maria Nekesa, July 29, 2009.

OI, Simon Masafu, October 19, 2010.

OI, Solomon Khisa, October 28, 2010.

OI, Solomon Naliakho, November 30, 2010.

Otele, O.S. (2010). Perspectives on Child Labour in Kenya; A Case of Malakisi Tobacco Farms, 2003-2010.M.A Thesis, University of Nairobi, Nairobi.

Otieno, J. (1998). Tobacco Under Contract: Agricultural Development and Environmental Change in Kuria District, Western Kenya. Ph. D Dissertation, University of Illinois at Urbana Champaign.

Palmer, R. \& Parsons, N. (eds.) (1983). The Roots of Rural Poverty in Central and Southern Africa. London: Heinemann.

Republic of Kenya, (1999).Bungoma District Development Plan, 1997-2001.Nairobi: Government Printer. 
Richards, P. (1983). "Ecological Change and the Politics of African Land use” African Studies Review, 26.

Rubert, S. (1997).A Most Promising Weed: A History of Tobacco Farming and Labour in Colonial Zimbambwe, 1890-1945.Athens: Ohio University Press.

Scott, C. (1982).The Evils of the Tobacco Habit. Dwilight Balin: Forgotten Books.

Spencer, P. (1984).Pastoralists and the Ghost of Capitalism. Production Pastorale et Societe.

Stubbs, J. (1985).Tobacco on the Periphery: A Case Study in Cuban Labour History. 1860-1958.Cambridge: Cambridge University Press.

Valentine, D., Bernstein, H.\& Brass, T.(1992).Plantations, Proletarians and Peasants in Colonial Asia. London: Frank Cass.

Van Willingen, J \& Eastwood, S. (1998).Tobacco Culture; Farming Kentucky’s Burley Belt. $\quad$ Kentucky: Kentucky University Press.

Werner, P. A. (1939). Tobacco land. New York: Ullan Press.

Wilbert, J. (1987). Tobacco and Shamanism in South America. New York: Yale University Press.

--------.(1991). The Smoke of the Gods; A Social History of Tobacco.(New York: Eric Barns, Temple University Press.

World Bank (1986).cited in Isaacman, A. Cotton is the Mother of Poverty. 